\title{
CLIMATIC SELECTION IN THE LAND SNAIL ARIANTA ARBUSTORUM IN DERBYSHIRE, ENGLAND
}

\author{
DAVID T. PARKIN \\ Department of Zoology, West Mains Road, Edinburgh EH9 3JT
}

Received 23.iii.71

\section{INTRODUGTION}

Ecological genetics is concerned with accounting for the amount of genetic diversity in natural populations of animals and plants. Problems arise in conjunction with field studies over the selection of genetically controlled characters for examination. For example, gross morphological characters such as wing structure or eye colour of Drosophila species are attractive because of their relative ease of assay. However, they are frequently at such a selective disadvantage that they are more or less absent outside the population cage. This makes them impracticable for field work.

There has been a considerable interest in the selective forces acting upon the visibly detectable varieties (morphs) of land snails. Visual selection for crypsis by predators has been shown to be of importance in controlling the relative frequencies of the various phenotypes of Cepaea nemoralis (Cain and Sheppard, 1950; Currey, Arnold and Carter, 1964), C. hortensis (Clarke, 1962), Cochlicella acuta (Dr G. A. Lewis, personal communication), Hygromia striolata (B. G. Clarke et al., personal communication), and Arianta arbustorum (Parkin, 1971), among others. Of these, the first two have attracted most attention, partly because of their conspicuous and remarkable polymorphisms. In $C$. nemoralis for example, at least 10 loci are known to control characters manifest in the colour and banding of the shell (Cain, Sheppard and King, 1968). This variation makes the detection of selective forces other than those directly associated with crypsis difficult (see for example Cain and Currey, 1963a, b; Goodhart, 1963; also Clarke, 1962; Carter, 1967; Clarke, 1969). Simpler variation will result in less interaction between the various polymorphisms, and should ease the detection of consistencies in the natural distribution of the genes in nature.

It was with this in mind that a survey of the distribution of the various morphs of Arianta arbustorum was initiated. This species appears to have only two phenotypes for colour: brown and yellow (or to be more precise, albino, for the character is one of absence of shell pigment rather than presence of yellow as in Cepaea spp). Arianta has three alleles for banding (Cook and King, 1966), but two of these cannot be reliably distinguished in natural populations. They are therefore combined as "banded", the third allele being for the unbanded condition. Brown and banded are dominant to yellow and unbanded respectively, and the two loci are closely linked $(r<1$ per cent.; Cook and King, 1966), so they effectively form a supergene.

\section{The study AREA}

This paper reports the results of a survey of the populations of Arianta inhabiting the valleys of the Rivers Wye and Derwent in Derbyshire, 
Northern England. The former of these runs east from Buxton, cutting a deep valley through the carboniferous limestone to Bakewell, where it joins the River Derwent and flows south-east to Matlock. The distance from Buxton to Bakewell is 11 miles, from here to Matlock being a further 8 miles. Samples were taken between the first two of these towns, and further collections made around Matlock.

There is considerable difference in rainfall between the two extremes of the survey area (table 1). This results in differences in vegetation. The main river valleys contain both woodland and open country. The woodlands consist primarily of ash (Fraxinus excelsior) in the west, merging to sycamore (Acer pseudoplatanus) and oak (Quercus sp.) in the centre of the area. On the dry exposed hillsides in the east, hawthorns (Crataegus monogyna), hazel (Corylus avellana) and birch (Betula sp.) are more abundant. The ground under the trees in the west is mossy and dark for much of the year, carpeted in places with dog's mercury (Mercurialis perennis) in high summer. Towards the east the trees thin out and the woods are carpeted with grass and herbs. The non-woodland habitats are rich and lush in the

TABLE 1

The mean annual rainfall for points along the valley of the rivers $W y e$ and Derwent in Derbyshire

$\begin{array}{llcc}\text { Locality } & \text { Dale } & \begin{array}{c}\text { Km. east } \\ \text { of Buxton }\end{array} & \begin{array}{c}\text { mean rainfall } \\ \text { (inches) }\end{array} \\ \text { Buxton (1) } & \text { Wye } & 0 & 48 \cdot 39 \\ \text { Buxton (2) } & \text { Wye } & 2 \cdot 0 & 45 \cdot 36 \\ \text { Hargate } & \text { Chee } & 5 \cdot 0 & 44 \cdot 01 \\ \text { Wheston* } & \text { Millers } & 6 \cdot 2 & 42 \cdot 14 \\ \text { Tideswell } & \text { Millers } & 8 \cdot 2 & 40 \cdot 31 \\ \text { Monyash* } & \text { Monsal } & 8.5 & 41 \cdot 18 \\ \text { Chatsworth* } & \text { Monsal } & 19.5 & 32.60 \\ \text { Whatstandwell } & \text { Matlock } & 25.8 & 33.77\end{array}$

* These points lie very close to, but not actually in the line of the Wye-Derwent Valley.

west with long grass and thick herbs on the sheltered north-facing slopes. The cover is thinner on more exposed hillsides, and declines generally in height and richness towards the east.

It has already been shown (Parkin, 1971) that visual selection for crypsis is operative in this area. Higher proportions of yellow shells are found in populations of Arianta from non-woodland localities. Cameron (1970) has shown that this habitat can be subdivided into short grass, mixed herbage and nettles, each of which has its own particular composition of snail species. If trends are to be detected in the ecological genetics of Arianta, these subdivisions must be taken into consideration.

Sampling areas were less than 25 metres in diameter and care was taken to separate sampling points to avoid the complications of gene flow. The data are too extensive to report here but can be found in Parkin (1969, Chapter 2, Tables 4, 9, 10, 16 and 17).

\section{The ecological genetics of Arianta}

\section{(a) The Wye-Derwent Valley}

Because of the change of rainfall along this valley, the area was divided into five approximately equal areas (Parkin, 1971). The relationship was determined between the proportion of Arianta in each sample and its position 
on the rainfall gradient. This is shown in fig. 1 (a) for the woodland habitats. Rank correlation coefficients were computed because of the nonnormal nature of the data, and these are given in table 2. There is a significant decline in the relative abundance of Arianta from west to east in three of the five habitats.

The area of each of the subunits of the Wye-Derwent Valley is relatively small. Consequently, there are few examples of each habitat in them, apart from woodland, which is widespread. It is inevitable, then, that there are few samples from some habitats and that the number of Arianta in them is sometimes small, for the species is not universally common. As a result, all samples containing five or more Arianta which could be scored for colour and banding have been included in this section.

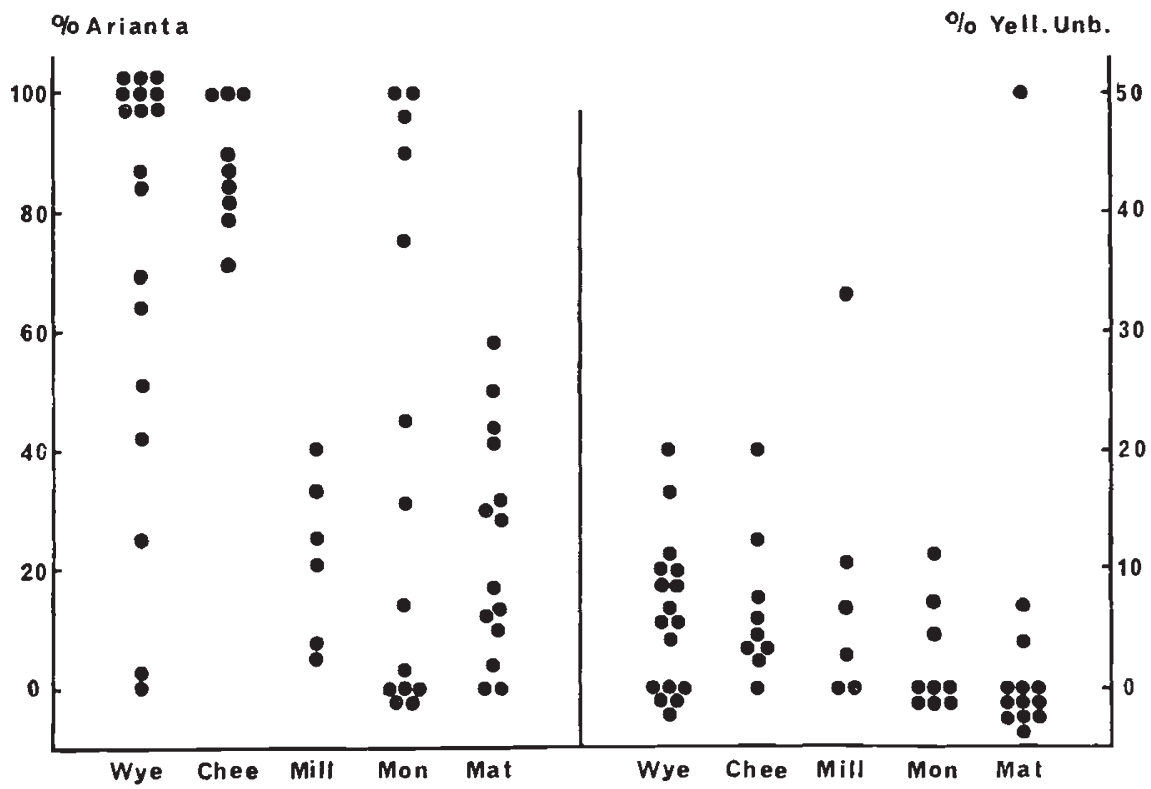

Fig. 1.-(a) The left-hand side shows the proportion of Arianta arbustorum (L.) in each sample of land snails taken from the valley of the rivers Wye and Derwent in Central Derbyshire. (b) The right-hand side shows the proportion of unbanded yellow individuals among the Arianta from the same region. Wye $=$ Wyedale; Chee $=$ Cheedale; Mill $=$ Millersdale; Mon $=$ Monsaldale; Mat $=$ Matlock.

The relationship between rainfall and the proportion of yellow unbanded (YU) has been determined (as in fig. 1 (b) for woodland). Table 2 shows the rank correlation coefficients for each habitat, and three of the five are significantly negative. It seems therefore that the proportion of both Arianta within the samples, and YU within the Arianta declines from west to east. The former of these results might be predicted from the work of Boycott (1934), Stratton (1956) and Cameron (1970), all of whom consider Arianta to be a damp-loving species. The latter result is less expected.

In each subunit, the habitats which include two or more samples of Arianta have been examined and the association between the frequency of YU and the proportion of Arianta in the sample has been determined (table 3). Obviously with such small numbers, many of the associations are not significant. However, it is evident that 19 of the sets show a positive and only 
TABLE 2

The relationship between the position of the sample in the dales from west to east and (a) the proportion of Arianta in the sample and (b) the frequency of yellow unbanded in the Arianta for each habitat separately

\begin{tabular}{|c|c|c|c|c|c|c|}
\hline & \multicolumn{3}{|c|}{ Percentage Arianta in sample } & \multicolumn{3}{|c|}{ Percentage YU in Arianta } \\
\hline & $\begin{array}{c}\text { Rank } \\
\text { correlation } \\
\text { coefficient }\end{array}$ & $\begin{array}{c}\text { Number } \\
\text { of } \\
\text { samples }\end{array}$ & $\begin{array}{c}\text { Probability } \\
\text { that } \\
\text { coefficient } \\
\text { equals unity }\end{array}$ & $\begin{array}{c}\text { Rank } \\
\text { correlation } \\
\text { coefficient }\end{array}$ & $\begin{array}{l}\text { Number } \\
\text { of } \\
\text { samples }\end{array}$ & $\begin{array}{c}\text { Probability } \\
\text { that } \\
\text { coefficient } \\
\text { equals unity }\end{array}$ \\
\hline Short grass & $-0 \cdot 35$ & 56 & $0 \cdot 02$ & -0.57 & 18 & $0 \cdot 02$ \\
\hline Long grass & -0.45 & 25 & $0 \cdot 02$ & -0.49 & 13 & $0 \cdot 10$ \\
\hline Mixed herbage & $-0 \cdot 20$ & 38 & $0 \cdot 25$ & -0.48 & 19 & $0 \cdot 04$ \\
\hline Tall herbage & $-0 \cdot 22$ & 27 & $0 \cdot 27$ & $-0 \cdot 12$ & 25 & 0.06 \\
\hline Woods & -0.54 & 61 & $0 \cdot 001$ & -0.47 & 54 & $0 \cdot 00 \mathrm{I}$ \\
\hline
\end{tabular}

three a negative association. The null hypothesis of no association is therefore highly unlikely $(\mathrm{P}<0.001)$.

This result could conceivably be due to the smallness of some of the samples. With a low average proportion of $\mathrm{YU}$ in the populations, small samples would be more likely to exclude the rare form than to include it. This would result in a low estimated frequency in the localities where Arianta is scarce. However, there is no evidence of a trend towards the smaller samples having a lower frequency of $\mathrm{YU},(\mathrm{P} \bumpeq 0 \cdot 3)$, so this explanation can be discarded.

\section{(b) Cunningdale}

Cunningdale is the westernmost of the side-dales of the Wye Valley. It is burned regularly at the lower end and grazed by sheep higher up; conse-

TABLE 3

The values of the rank correlation coefficient between the proportion of unbanded yellow Arianta in the sample and the proportion of Arianta taken at the same point from each habitat within each dale in the Wye-Derwent Valley system

\begin{tabular}{lllc} 
Dale & \multicolumn{1}{c}{ Habitat } & RHO & Number of samples \\
Wye & Short grass & $-0 \cdot 36$ & 8 \\
Wye & Long grass & $+1 \cdot 00$ & 4 \\
Wye & Mixed herbage & $+0 \cdot 37$ & 7 \\
Wye & Tall herbage & $+0 \cdot 80$ & 4 \\
Wye & Woods & $+0 \cdot 16$ & 17 \\
Chee & Long grass & $+0 \cdot 90$ & 4 \\
Chee & Mixed Herbage & $+0 \cdot 78$ & 5 \\
Chee & Tall herbage & $+0 \cdot 74$ & 7 \\
Chee & Woods & $-0 \cdot 07$ & 9 \\
Millers & Short grass & +0.43 & 5 \\
Millers & Long grass & $+1 \cdot 00$ & 2 \\
Millers & Tall herbage & $+0 \cdot 62$ & 8 \\
Millers & Woods & $+0 \cdot 21$ & 6 \\
Monsal & Short grass & +0.50 & 2 \\
Monsal & Mixed herbage & +0.50 & 3 \\
Monsal & Tall herbage & -0.50 & 3 \\
Monsal & Woods & +0.36 & 9 \\
Matlock & Short grass & +0.50 & 2 \\
Matlock & Long grass & $+1 \cdot 00$ & 2 \\
Matlock & Mixed herbage & +0.13 & 3 \\
Matlock & Tall herbage & $+1 \cdot 00$ & 3 \\
Matlock & Woods & +0.22 & 13 \\
& & &
\end{tabular}


quently it is virtually treeless. The ground is carpeted with rank grass, shorter at the top of the slopes, and mixed with herbs such as Black Knapweed (Centaurea nigra), nettles (Urtica dioica) and Coltsfoot (T ussilago farfara) at the bottom.

Most samples contain Arianta and $C$. nemoralis, about half include C. hortensis as well. The U-test (Whitney and Mann, 1947) shows that there is no difference between the habitats in the proportion of Arianta, but that the species is scarcer in the samples from south-facing localities $(P<0.05)$. This result is also consistent with the earlier ecological studies showing the species to be damp-loving, for evaporation is lower on north-facing slopes and in the valley bottom.

Cunningdale differs from the Wye-Derwent Valley in having a relatively large number of samples containing over 10 Arianta scorable for colour and banding. Consequently, the smaller samples can be omitted from the analysis of shell-character polymorphism. It is worth noting that the results obtained when they are included are similar but less significant-a factor which increases confidence in the results of the previous section.

$\mathrm{YU}$ is less dependent upon habitat than aspect. There is no significant difference in frequency between the habitats $(P \bumpeq 0.5)$, but YU are significantly more abundant on north-facing slopes than elsewhere. There is no evidence of association between the frequency of $\mathrm{YU}$ and the proportion of Arianta in the samples from either north-facing $(P \bumpeq 0.5)$ or south-facing $(P \bumpeq 0.5)$ slopes. When the data from the two sides are combined with those from the valley bottom, there is a positive association within the dale as a whole, which is just significant $(\mathrm{P}<0.05)$.

\section{(c) Deepdale}

Deepdale is about $1 \frac{1}{2}$ miles long and opens into Wyedale from the south. It is narrow with steep sides, and consequently is well sheltered from the wind. Evaporation must be slow because the bottom of the dale is very damp. Arianta abounds in the moister parts of Deepdale.

When the samples are divided into habitat groups, there is no overall trend in the distribution of $\mathrm{YU}$. However, Deepdale differs from the areas discussed previously because the banded yellow morph (YB) occurs in many of the samples. This form comprises a higher proportion of the yellow shells in populations where (for Deepdale) yellows are less abundant $(\mathrm{P}<0.001)$. Thus where banded browns are at a high frequency, the yellows are more banded. In the areas considered prior to Deepdale, with relatively few shells other than YU and BB, there has generally been a negative association between the frequency of $\mathrm{BB}$ and the proportion of Arianta in the samples. This is not evident in the samples from Deepdale, there being no consistency in either the magnitude or the sign of the correlation coefficients.

\section{Discussion}

It has been shown elsewhere (Parkin, 1971) that predation has a marked effect upon the relative frequencies of yellow and brown in the populations of Arianta from the valleys of the rivers Wye and Derwent. Predators which hunt visually take a higher proportion of the former from woodland than adjacent non-woodland localities. The present results are not explicable by recourse to visual selection. Unlike Cepaea (Cain and Sheppard, 1950), 
yellow Arianta never look green when occupied by a snail, yet $\mathrm{YU}$ is more abundant in the west where the vegetation is lush. They might be expected to occur less in these darker green habitats, but they are more abundant here. In woodlands, the situation is more extreme, for little grows under the trees in the west and the background is brown for much of the year, becoming grassy towards the east as the trees thin out. Although visual selection is imposed upon these populations its effects can only be detected between habitats, and within habitats other morph-controlling agencies must apply.

Arnold (1968) has shown that in some valleys of the Pyrenees, populations of $C$. nemoralis have higher proportions of unbanded and yellow individuals at higher altitudes than lower down. He interprets this as indicating that the yellow unbanded morph is more resistant to extremes of heat and cold. He discusses the results of survival experiments and concludes that these support his views. Jones (in preparation) considers the varied design of these experiments to reduce their reliability.

No data is available from Derbyshire concerning fluctuations in temperature, and this climatic factor can only be approached by a survey on a bigger scale than the present paper (Parkin, in preparation). However, some estimate of the severity of the micro-climate for Arianta will be given by its occurrence in the community relative to Cepaea. C. nemoralis is more capable of enduring high temperature and aridity than Arianta, and this is reflected in the latter's decline in abundance from west to east. Similarly, within individual dales, Arianta is scarcer high on the sides where drainage is more rapid, vegetational cover less, and insolation of the ground high. It is the samples with more Arianta that possess a larger proportion of unbanded yellow, both within individual dales and more widely.

Carson (1956) examined populations of Drosophila robusta for the number and occurrence of chromosomal inversions. He found that populations towards the margins of the species' range were more homozygous for inversions than populations nearer the centre. A similar situation was found to hold for populations of $D$. willistoni (da Cunha et al., 1959). Three species of Drosophila which reach the margins of their ranges in Florida are also less variable that at the centre of their distributions (Carson and Heed, 1964).

It is evident that Arianta generally exhibits more colour and banding polymorphism in the damper west of the Wye Valley, and also, more locally, in positions where the species fares better relative to Cepaea. This could be a reflection of the same effect. It is true that the Drosophila results are for actual chromosome inversions, but it is possible that the low recombination rate between the colour and banding loci of Arianta (Cook and King, 1966) is due to the fact that they are included within an inversion.

The populations of Arianta from Cunningdale contain neither YB nor BU individuals, whereas those in Deepdale frequently include the former. These dales are both among the best areas for Arianta in Derbyshire, and are but a few hundred yards apart.

The "variation" of a sample may be estimated using Shannon and Weaver's index of diversity, $\mathrm{H}^{\prime}$ (Pielou, 1966). There is no evidence that this parameter increases within Deepdale either in association with the proportion of Arianta, or with the increasing variability of the species composition of the sample. It thus appears that the species is not responding in a simple way to the increasing suitability of the environment by becoming more polymorphic. It must be concluded that the unbanded yellow morph 
survives better, relative to the brown banded one, in the damper and lusher habitats, but that this simple relationship breaks down when a third morph is present in appreciable frequencies.

In any event, it seems clear that climatic factors, associated with rainfall, exercise a significant selective influence upon the frequencies of shell-colour morphs of Arianta arbustorum. This influence is additional to the selective effects of predation, which have already been described (Parkin, 1971).

\section{Summary}

1. Arianta arbustorum (L.) is a land snail, polymorphic for colour and banding. Brown shell colour is dominant to yellow; banding is dominant to nonbanding.

2. In Derbyshire, populations are subjected to visual selection by predators, and non-visual selection resulting in a higher proportion of unbanded yellow individuals in the wetter parts of the range of the species.

3. Furthermore, this morph is more abundant locally where the species forms higher proportions of the community relative to Cepaea nemoralis and C. hortensis.

4. It is argued that this is due to selection favouring the unbanded yellow morph in damper or more humid localities.

Acknowledgments.-The material forming the basis for this study was collected jointly by R. A. D. Cameron, J. J. D. Greenwood and myself. I should like to thank my supervisor, Professor A. J. Cain, for continual encouragement and advice. All three discussed the work with me. Professor Cain, Dr Bryan Clarke and Mr J. S. Jones read and criticised the manuscript. I am grateful to my wife for drawing the graphs, checking the tables and helping with the fieldwork. The work was undertaken while I was in receipt of a Science Research Gouncil Post-Graduate Studentship. I am indebted to Professors R. Dennell and A. J. Cain for the facilities which they provided at Manchester and to Professors J. M. Mitchison and P. M. B. Walker for those at Edinburgh.

\section{REFERENCES}

ARNold, R. w. 1968. Studies on Cepaea: vii. Climatic selection in Cepaea nemoralis (L.) in the Pyrenees. Phil. Trans. Roy. Soc. Lond., B, 253, 549-593.

BoycotT, A. E. 1934. The habitats of land mollusca in Britain. 7. Ecol., 22, 1-35.

Cain, A. J., And currey, J. D. 1963a. Area effects in Cepaea. Phil. Trans. Roy. Soc. Lond., $B, 246,1-81$.

CAIN, A. J., AND CURREY, J. D. 1963b. The causes of area effects. Heredity, 18, 467-471.

GAIN, A. J., AND SHEPPARD, P. M. 1950. Selection in the polymorphic landsnail Cepaea nemoralis. Heredity, 4, 275-294.

CAIN, A. J., SHEPPARD, P. M., AND KING, J. M. B. 1968. Studies on Cepaea. I. The genetics of some morphs and varieties of Cepaea nemoralis (L.). Phil. Trans. Roy. Soc. Lond., B, 253, 383-396.

CAMERON, R. A. D. 1970. Differences in the distribution of three species of helicid snail in the limestone district of Derbyshire. Proc. Roy. Soc. Lond., B, 176, 131-159.

Carson, H. L. 1956. Marginal homozygosity for gene-arrangement in D. robusta. Science, $123,630-631$.

CARSON, H. L., AND HEED, W. B. 1964. Structural homozygosity in marginal populations of Nearctic and Neotropical species of Drosophila in Florida. Proc. Natl. Acad. Sci., 52, 427-430.

GARTER, M. A. 1967. Selection in mixed colonies of Cepaea nemoralis (L.) and C. hortensis (Mull). Heredity, 22, 117-139.

CLARKE, B. 1962. Natural selection in mixed populations of two polymorphic snails. Heredity, 17, 319-345.

CLARKE, B. 1969. The evidence for apostatic selection. Heredity, 24, 347-352. 
COOK, L. M., AND KING, J. M. B. 1966. Some data on the genetics of shell-character polymorphism in the snail Arianta arbustorum. Genetics, 53, 415-425.

CURREY, J. D., ARNOLD, R. W., AND CARTER, M. A. 1964. Further examples of variation of populations of Cepaea nemoralis with habitat. Evolution, 18, 111-117.

DA CUNHA, A. B., DOBZHANSKy, TH., PAVlovsky, O., AND SPASSKY, B. 1959. Genetics of natural populations. XXVII. Supplementary information on the chromosomal polymorphism in Drosophila willistoni in its relation to the environment. Evolution, 13, 389-404.

GOODHART, G. B. 1963. Area effects and non-adaptive variation between populations of Cepaea (Mollusca). Heredity, 18, 459-471.

PARKIN, D. T. 1969. On the polymorphism of the land snail Arianta arbustorum (L.). Ph.D. Thesis, Manchester University.

PARKIN, D. T. 1971. Visual selection in the landsnail Arianta arbustorum (L.). Heredity, $26,35-47$.

PARKIN, D. T. (in prep.). Polymorphism of the landsnail Arianta arbustorum (L.) in Britain. PIELOU, E. G. 1966. The measurement of diversity in different types of biological collections. 7. Theoret. Biol., 13, 131-144.

stratton, L. w. 1956. On Arianta arbustorum. 7. Conchology, 23, 405-412.

WHITNEY, D. R., AND MANN, H. B. 1947. On a test of whether one of two random variables is statistically larger than the other. Ann. Math. Stat., 18, 30-60. 